\title{
ANTIBACTERIAL ACTIVITY OF FOMITOPSIS BETULINA CULTURAL LIQUID
}

\author{
Tetiana Krupodorova ${ }^{1}$ \\ krupodorova@gmail.com \\ Victor Barshteyn ${ }^{l}$ \\ barmash14@gmail.com \\ Elena Pokas \\ Laboratory of medical microbiology with museum of pathogenic for human microorganisms \\ Institute of Epidemiology and Infectious Diseases of the National Academy of \\ Medical Sciences of Ukraine \\ 5 M. Amosov str., Kyiv, 03038, Ukraine \\ lenapokas@gmail.com \\ ${ }^{1}$ Laboratory for Plant Extraction and Bioconversion \\ Institute of Food Biotechnology and Genomics of the National Academy of Sciences of Ukraine \\ 2 a Osipovskogo str., Kyiv, 04123, Ukraine
}

\begin{abstract}
The antibacterial activity of Fomitopsis betulina cultural liquid (native, native concentrated, lyophilized, dried) against standard bacteria (Escherichia coli ATCC 25922, Pseudomonas aeruginosa ATCC 27853, Staphylococcus aureus ATCC 25923), and clinical isolates (Acinetobacter baumannii 50/1496 MBL, A. baumannii 88/2995 MBL, E. coli 116/3196 KPC, Klebsiella pneumoniae 6/509 ESBL, AmpC, KPC, P. aeruginosa 99/3066 MBL, P. aeruginosa 125/3343 MBL, S. haemoliticus 22/824 MRSA, $S$. aureus $134 / 3569$ MRCNS) has been evaluated by the serial dilutions method. The antibacterial activity of $F$. betulina against $S$. haemoliticus and A. baumannii has been found for the first time. All samples of $F$. betulina cultural liquid demonstrated the inhibitory effect against standard bacterial strains at the minimum bactericidal concentration (MBC) ranging from $>2.0$ up to $18.75 \mathrm{mg} / \mathrm{ml}$, and against multidrug-resistant clinical isolates with $\mathrm{MBC}$ from 7.8 up to $48.42 \mathrm{mg} / \mathrm{ml}$. The dried $F$. betulina cultural liquid showed the highest antimicrobial activity against standard bacteria and clinical isolates, except A. baumannii 50/1496 MBL, while native concentrated cultural liquid was the most effective against this pathogen. The study showed that the antibacterial activity of the cultural liquid of $F$. betulina was improved by concentration and drying. The results obtained indicate that $F$. betulina cultural liquid contains alternative antimicrobial agents, useful for the treatment of bacterial diseases and might be a perspective substance for the pharmaceutical industries.
\end{abstract}

Keywords: antibacterial activity, Fomitopsis betulina, cultural liquid, standard bacteria, multidrug-resistant clinical isolates.

DOI: $10.21303 / 2504-5695.2019 .001066$

\section{Introduction}

Basidiomycete Fomitopsis betulina (Bull.) B.K. Cui, M.L. Han and Y.C. Dai (previously Piptoporus betulinus), also known as birch polypore, birch bracket, or razor strop, is a very common, perennial, widespread throughout the world, brown rot macrofungus, mostly being found in northern temperate zones in Europe, North America, and Asia on dead trees of Betula species and may grow as a parasite on living trees. For a long time fruiting bodies of this species were applied in folk medicine. The results of modern investigations confirmed useful biological properties for prophylactic and therapeutic application due to the antibacterial, antiviral, anti-parasitic, anti-inflammatory, immunomodulating, anticancer, and neuroprotective activities [1]. One of its important properties is antibacterial activity, which is particularly relevant nowadays, considering a number of known and the occurrence of new bacteria species, including drug-resistant pathogenic bacteria strains, causing to different diseases. Previous studies demonstrated that $P$. betulinus extracts had the antibacterial activity against different bacterial species. Polyporenic acid, purified from the 
birch polypore benzene extract, inhibited growth of Brucella sp. [2]. This compound, obtained by benzene extraction from $P$. betulinus carpophores and another triterpenoid - polyporenic acid A, identified in the ethanol extracts, was effective against Bacillus subtilis and Sacina lutea growth $[3,4]$. A crude extract from P. betulinus fruit bodies, collected in Spain, inhibited the growth of several bacteria like Bacillus subtilis, Mycobacterium smegmatis, Pseudomonas aeruginosa, Serratia marcescens, Staphylococcus aureus [5]. Antibiotic piptamine, isolated from ethyl acetate extract of $P$. betulinus Lu 9-1 cultural liquid, showed the activity against bacteria $S$. aureus strains, $B$. subtilis, Enterococcus faecalis, Escherichia coli at Minimum Inhibitory Concentration (MIC) values from 0.78 up to $>12.5 \mu \mathrm{g} / \mathrm{ml}$ [6]. Further investigation [7] also demonstrated the antibacterial potential of piptamine: both methanol and dichloromethane extracts suppressed the growth of $B$. subtilis and E. coli. Chloroform and butanol extracts from fruit bodies of Bulgarian P. betulinus were active against $S$. aureus [8]. The antibacterial activity of the chloroform extract of birch polypore has been also found in case of Bacillus spp., Rhodococcus equi, S. aureus [9]. The compositions from different aggregate forms of mycelium and their extracts of medicinal mushrooms, including $P$. betulinus, showed inhibition of $S$. aureus and E. coli higher than $99 \%$ [10]. An alcohol extract of $P$. betulinus has been found effective against E. faecalis [11]. Ethanol extracts of $P$. betulinus, obtained from fruit bodies, collected in Austria, were active against B. subtilis (MIC $62.5 \mu \mathrm{g} / \mathrm{ml}$, minimum bactericidal concentration (MBC) $500 \mu \mathrm{g} / \mathrm{ml}$ ), S. aureus (MIC/MBC $31 \mu \mathrm{g} / \mathrm{ml}$ ) [12]. Some triterpenoic compounds ( $3 \beta$-acetoxy-16 $\alpha$ hydroxyl-24-oxo-5 $\alpha$-lanosta-8-ene-21-oic acid, betulinic acid, polyporenic acid C, ergosterol peroxide, 9,11-dehydroergosterol peroxide, (25S)-(+)-12 $\alpha$-hydroxy-3 $\alpha$-methylcarboxyacetate-24-methyllanosta-8,24(31)-diene-26-oic acid, and (25S,3'S)-(+)$12 \alpha$-hydroxy-3 $\alpha$-(3'-hydroxy-3'-methyl glutaryloxy)-24-methyllanosta-8,24(31)-dien-26-oic acid) with different levels (from medium to very weak) of antibacterial activity against $B$. subtilis, $S$. aureus, $P$. aeruginosa and $E$. coli have been isolated from the ethyl acetate extract of the $P$. betulinus fruiting bodies [13].

Thus, some research has been done to investigate the antibacterial potential of birch polypore, using different methods, test bacteria, samples of mushroom, fractions or single compounds. There are still many ways to explore this relevant and important problem. The culture liquid of the fungus contains a full complex of biologically active substances, which is impossible in the case of extraction by one or another solvent. It is not excluded that a number of such substances potentiate the action of each other. The aim of this research was to evaluate the antibacterial activity of $\mathrm{Fo}_{\mathrm{O}}$ mitopsis betulina (Bull.) B.K. Cui, M.L. Han and Y.C. Dai, strain 327 cultural liquid against some standard bacteria and clinical isolates.

\section{Material and Methods}

Fomitopsis betulina was supplied by the IBK [14] and were maintained in necessary conditions [15]. The bacterial standard strains Escherichia coli ATCC 25922, Pseudomonas aeruginosa ATCC 27853, Staphylococcus aureus ATCC 25923, and clinical isolates Acinetobacter baumannii 50/1496 MBL, A. baumannii 88/2995 MBL, E. coli 116/3196 KPC, Klebsiella pneumoniae 6/509 ESBL, AmpC, KPC, P. aeruginosa 99/3066 MBL, P. aeruginosa 125/3343 MBL, S. haemoliticus 22/824 MRSA, S. aureus 134/3569 MRCNS were kindly supplied by the Culture Collection of Microorganisms of the Institute of Epidemiology and Infectious Diseases of the National Academy of Medical Sciences of Ukraine. The bacterial strains were selected from standard ones as much as used for similar studies and because of their pathogenic characteristics. Tested microorganisms were prepared as in the study [15].

Culture media and conditions are consistent with those in a previous study [15].

The dry weight was determined as follows. After preparation of mycelium and cultural liquid [15] culture liquid was frozen $\left(-80^{\circ} \mathrm{C}\right)$ and lyophilized (Telstar Cryodos-80, Terrassa, Barcelona, Spain) or dried at $60{ }^{\circ} \mathrm{C}$ (Snol-58/350, UMEGA, Republic of Lithuania) to a constant weight.

The antibacterial activity of $F$. betulina cultural liquid (native, native concentrated, lyophilized, and dried) against bacterial standard strains and clinical isolates was determined by the series of the twofold dilutions method [16]. Initial solutions of the F. betulina culture liquid were obtained by measuring a certain amount (in terms of dry matter): native cultural liquid (its concen- 
tration ranged from 0.146 up to $18.750 \mathrm{mg} / \mathrm{ml}$ ), concentrated native cultural liquid (with concentration between 0.75 and $96.85 \mathrm{mg} / \mathrm{ml}$ ), lyophilized, and dried samples of $F$. betulina culture liquid were dissolved in pure Dimethyl sulfoxide (DMSO) in concentration from 2.0 up to $250 \mathrm{mg} / \mathrm{ml}$. DMSO was chosen as a non-toxic solvent and due to its very good permeability through biological membranes. A test bacterial culture $(0.5 \mathrm{ml})$ in Mueller-Hinton broth (MHB) was added to the sterile tubes already containing the $0.5 \mathrm{ml}$ of twofold serially diluted samples of $F$. betulina cultural liquid in MHB. Positive controls were tubes with a bacterial suspension in $0.5 \mathrm{ml}$ of MHB, sterility controls - tubes with MHB. Negative controls were tubes with bacterial suspension in MHB with pure DMSO.

The minimum concentration (MIC) is the lowest concentration of the sample that will inhibit the visible growth of test-bacteria. The minimum bactericidal concentration (MBC) was defined as the lowest concentration of a sample that gave the complete absence of growth on the agar surface. Incubation was carried out at $37^{\circ} \mathrm{C}$ for 24 hours.

All the assays were carried out in triplicate. For the antimicrobial assay, the MBC which killed all the organisms was recorded.

\section{Results and Discussion}

In respect that using of different toxic solvents for extraction is often of no practical use in therapy we focused our study on different aggregate forms of the mushroom cultural liquid (native, native concentrated, lyophilized, and dried). Due to the color of the F. betulina cultural liquid samples in almost all test tubes, the determination of the MIC (the lowest concentration of the tested sample, able to inhibit the growth of bacteria) was complicated and, unfortunately, the saturated brown color of the serial dilutions of culture liquid blocked the establishing of MIC (Fig. 1).

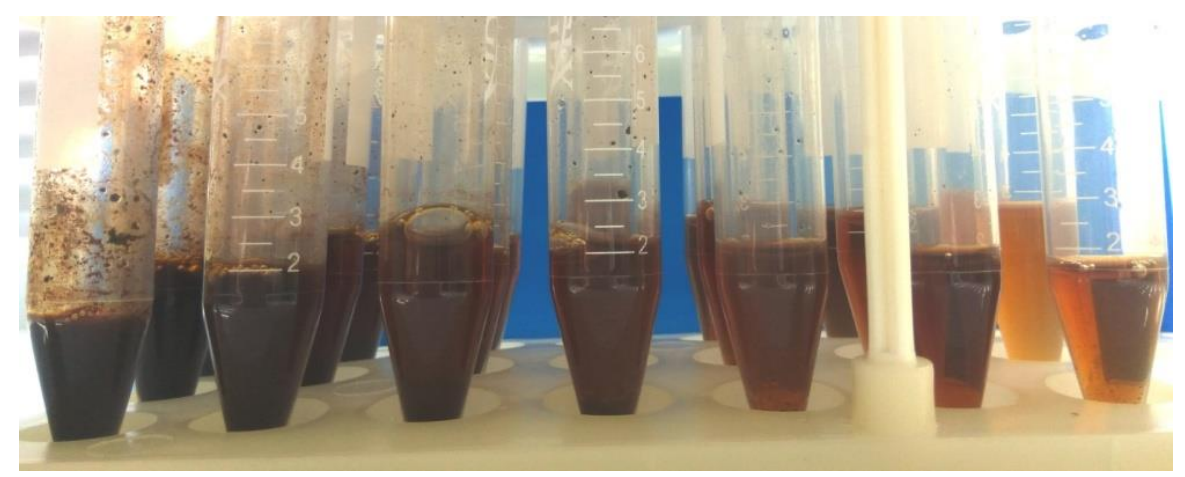

Fig. 1. Serial dilutions of dried F. betulina cultural liquid dissolved in DMSO

The MBC values against standard bacteria were determined as an evaluation of the antibacterial activity of the $F$. betulina samples (Table 1). The test bacteria possess varied susceptibility to the different samples of F. betulina cultural liquid. The native cultural liquid and lyophilized cultural liquid of $F$. betulina showed an exclusively static activity against test bacteria, presenting $\mathrm{MBC}$ of 18.75 and $7.8 \mathrm{mg} / \mathrm{ml}$, respectively. It was established a better efficiency of the native concentrated $F$. betulina cultural liquid, compared to its native form. These results are in agreement with a previous study [16] where the extracts from the liquid media showed antibacterial effects only when they were concentrated. The antibacterial activity of $F$. betulina cultural liquid also has been increased due to drying, which was expected. It was established, that pure DMSO (Negative control) possessed some antibacterial activity against test bacteria (Table 1), but in our experiments with the culture liquid, the presence of DMSO was less, than MBC of pure DMSO. Thus, the inhibition effect of our samples, dissolved in DMSO, on the bacterial growth, can be explained only by the antibacterial activity of $F$. betulina culture liquid. 
Table 1

Minimum bactericidal concentration $(\mathrm{mg} / \mathrm{ml})$ of $F$. betulina cultural liquid against standard bacteria

\begin{tabular}{cccc}
\hline Samples of $\boldsymbol{F}$. betulina & $\begin{array}{c}\text { S. aureus } \\
\text { ATCC 25923 }\end{array}$ & $\begin{array}{c}\text { E. coli } \\
\text { ATCC 25922 }\end{array}$ & $\begin{array}{c}\text { P. aeruginosa } \\
\text { ATCC 27853 }\end{array}$ \\
\hline Native cultural liquid & 18.75 & 18.75 & 18.75 \\
Native concentrated cultural liquid & 12.10 & 12.10 & 6.05 \\
Lyophilized cultural liquid & 7.8 & 7.8 & 7.8 \\
Dried cultural liquid & $>2.0$ & 15.6 & 3.9 \\
Negative control (DMSO) & 275.0 & 275.0 & 275.0
\end{tabular}

Our investigations confirm the results of previous studies that $F$. betulina possesses the antibacterial activity against similar bacteria [2, 5-13]. Samples of $F$. betulina cultural liquid, studied by us, possessed weaker activity against $S$. aureus ATCC 25923 , but were active against $P$. aeruginosa ATCC 27853, compared to the ethanolic extracts of $P$. betulinus fruit bodies [12]. Different species of macrofungi extracts were also tested against these standard bacteria [18-23]. The effectiveness of inhibition of S. aureus ATCC 25923 growth, influenced by the dried cultural liquid of $F$. betulina, dissolved in DMSO, was better, than other results of MBC: ethanol extracts of Amanita citrina, A. muscaria, A. pantherina, A. porphyria, Bjerkandera adusta, Clavicorona pyxidata, Fomes fomentarius, Fomitopsis pinicola, Lactarius aurantiacus, Panelluss typticus, Rhodocollybia maculate, Russula fragilis, Tubaria furfurace carpophores (5 mg/ml), Cortinarius armillatus, C. sanguineus, Daedaleopsis confragosa, Gymnopilus penetrans, Lactarius helvus, L. vellereus, Psilocybe fascicularis, Ps. lateritia, Scleroderma citrinum carpophores ( $>5 \mathrm{mg} / \mathrm{ml})$, Heterobasidion annosum, Lenzites betulinus, Stereum hirsutum, Thelephora terrestris, Trametes hirsuta, Trichaptum fuscoviolaceum carpophores $(>2.5 \mathrm{mg} / \mathrm{ml})$ [21]; ethyl acetate $(3.125 \mathrm{mg} / \mathrm{ml})$ and acetone $(12.5 \mathrm{mg} / \mathrm{ml})$ extracts from Cordyceps taii mycelia [22]; methanol extract of Coriolus versicolor carpophores $(5.0 \mathrm{mg} / \mathrm{ml})$ [20]; methanol $(62.5 \mathrm{mg} / \mathrm{ml})$, ethanol and aqueous extracts $(31.25 \mathrm{mg} / \mathrm{ml})$ of Pluerotus squarrosulus carpophores [18]; methanolic extract of Cantharellus cibarius carpophores $(20.0 \mathrm{mg} / \mathrm{ml})$ [19]. At the same time, the antimicrobial activity of $F$. betulina culture liquid against $S$. aureus ATCC 25923 was inferior to MBC of the chloroform extract $(1.56 \mathrm{mg} / \mathrm{ml})$ of Cordyceps taii mycelia [22], chloroform extract of Hygrophorus agathosmus $(125 \mu \mathrm{g} / \mathrm{ml})$, dichloromethane extract $(>1000 \mu \mathrm{g} / \mathrm{ml})$ of Suillus collitinus carpophores [23], and ethanol extract $(0.625 \mathrm{mg} / \mathrm{ml})$ of Hyphodontia paradoxa fruit body [21]. Gram-negative bacteria E. coli ATCC 25922 showed less sensitivity to tested samples of $F$. betulina cultural liquid than other mushroom extracts, reported in similar studies: MBC of the dichloromethane extract of Suillus collitinus sporokarps was $>1000 \mu \mathrm{g} / \mathrm{ml}$ [23], MBC of the ethanol extracts of fruiting bodies of 31 mushrooms like Amanita citrina, Am. muscaria, Am. pantherina, Am. porphyria, Bjerkandera adusta, Clavicorona pyxidata, Cortinarius armillatus, C. sanguineus, Daedaleopsis confragosa, Fomes fomentarius, Fomitopsis pinicola, Gymnopilus penetrans, Heterobasidion annosum, Hygrophoropsis aurantiaca, Hyphodontia paradoxa, Lactarius aurantiacus, L. helvus, L. vellereus, Lenzites betulinus, Panellus stypticus, Pseudoclitocybe cyanthiformis, Psilocybe fascicularis, Ps. lateritia, Rhodocollybia maculate, Russula fragilis, Scleroderma citrinum, Stereum hirsutum, Thelephora terrestris, Trametes hirsuta, Trichaptum fuscoviolaceum, Tubaria furfuracea were determined at concentration between 0.625 and $5 \mathrm{mg} / \mathrm{ml}$ [21]. In contrast, the tested samples of $F$. betulina cultural liquid inhibited the growth of $P$. aeruginosa ATCC 27853 significantly higher, than the methanol and ethanol extracts of Pluerotus squarrosulus fruit bodies with MBC at $62.5 \mathrm{mg} / \mathrm{ml}$ and $31.25 \mathrm{mg} / \mathrm{ml}$, respectively [18]. We noted that results of the studies, available in the literature, are entirely focused on evaluation of the antibacterial properties of mushroom extracts in contrast to this work.

In the last few decades the problem of resistance to antibacterial drugs is greatly global and has a great value for public health. Therefore, the next step was to study the antibiotic activity of $F$. betulina culture liquid against the most important drug-resistant strains that produce various types of betalactamase. Considering that the tested bacteria were clinical isolates with high antibi- 
otic resistance profile, the promising results have been established in our study (Table 2, Fig. 2, 3). The dried cultural liquid of $F$. betulina showed the highest antimicrobial activity against clinical isolates, except A. baumannii 50/1496 MBL. It is interesting, that E. coli 116/3196 KPC was more resistant to the native concentrated culture liquid of $F$. betulina, but in case of the dried culture liquid application this trend was not observed.

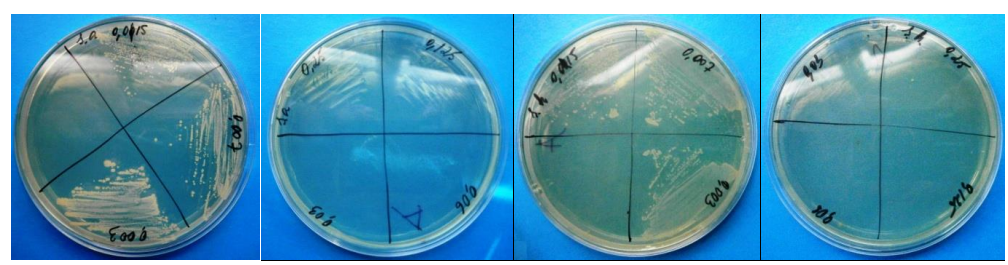

$a$

b

c

$d$

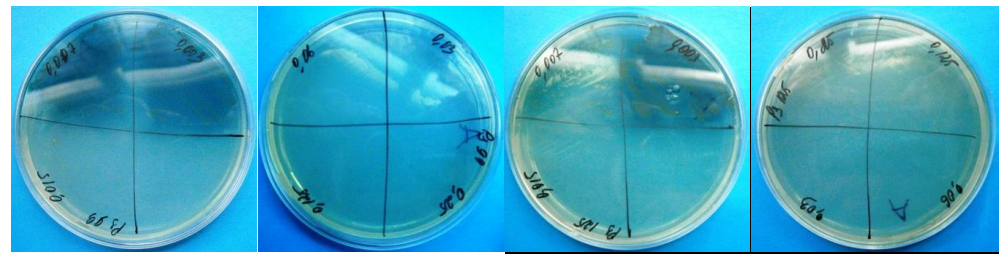

e $f$

$g$

$h$

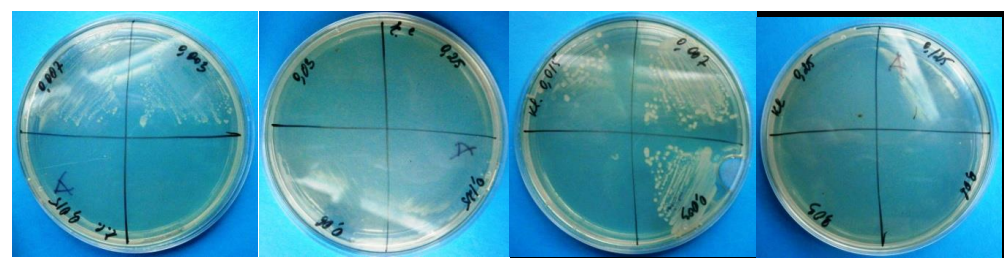

$i$

$k$

$l$

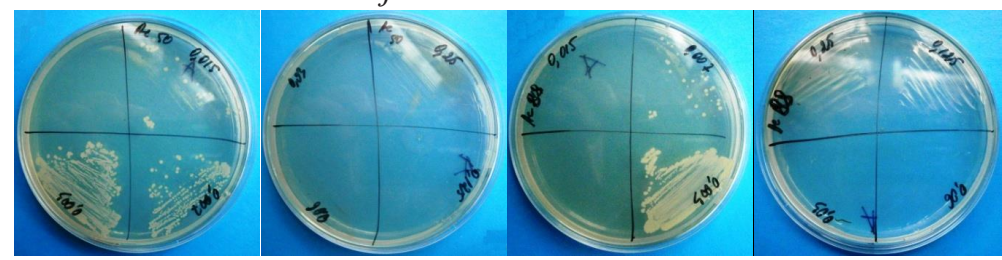

$m$

$n$

O

p

Fig 2. Illustrations of the antibacterial activity of $F$. betulina dried cultural liquid (depending on its concentration) on clinical isolates: $a, b-S$. aureus 22/824 MRSA;

$c, d-S$. haemoliticus 134/ 3569 MRCNS; e, f-P. aeruginosa 99/3066 MBL;

$g, h-P$. aeruginosa 125/3343 MBL; $i, j-E$. coli 116/3196 KPC; $k, l-K$. pneumoniae 6/509 ESBL; $m, n-A$. baumannii 50/1496 MBL; $o, p-$ A. baumannii 88/2995 MBL

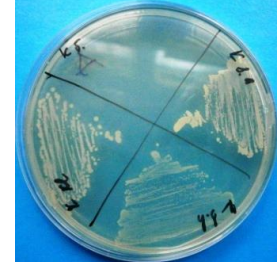

$a$

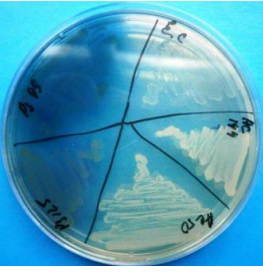

b

Fig. 3. Positive controls: $a$-growth of clinical isolates $S$. aureus 22/824 MRSA,

S. haemoliticus 134/3569 MRCNS, K. pneumoniae 6/509 ESBL, and control of cleanliness of

Mueller-Hinton broth on Mueller-Hinton agar; $b$-growth of clinical isolates $P$. aeruginosa 99/3066 MBL, P. aeruginosa 125/3343 MBL, E. coli 116/3196 KPC, A. baumannii 50/1496 MBL, A. baumannii 88/2995 MBL on Mueller-Hinton agar 
Table 2

Minimum bactericidal concentration $(\mathrm{mg} / \mathrm{ml})$ of $F$. betulina cultural liquid against clinical isolates

\begin{tabular}{ccc}
\hline Clinical isolates & Native concentrated cultural liquid & Dried cultural liquid \\
\hline S. aureus 22/824 MRSA & 24.21 & 15.6 \\
S. haemoliticus $134 / 3569$ MRCNS & 24.21 & 15.6 \\
P. aeruginosa $99 / 3066 \mathrm{MBL}$ & 12.10 & 7.8 \\
P. aeruginosa $125 / 3343 \mathrm{MBL}$ & 12.10 & 7.8 \\
E. coli $116 / 3196 \mathrm{KPC}$ & 48.42 & 7.8 \\
K. pneumoniae 6/509 ESBL & 24.21 & 15.6 \\
A. baumannii 50/1496 MBL & 12.10 & 15.6 \\
A. baumannii 88/2995 MBL & 12.10 & 7.8
\end{tabular}

\section{Conclusion}

Thus, the analysis of literature data indicates a significant interest of researchers to the studying of the antibacterial activity of higher fungi and their potential for the production of antibacterial compounds. Based on the obtained results, Fomitopsis betulina occupies a certain niche among the studied mushrooms. All forms of $F$. betulina cultural liquid (native, native concentrated, lyophilized, and dried), used in this study, were found to have the antibacterial activity in varying degrees against tested microorganisms: standard bacterial strains S. aureus ATCC 25923, E. coli ATCC 25922, P. aeruginosa ATCC 27853 at concentration from $>2.0$ up to $18.75 \mathrm{mg} / \mathrm{ml}$, and drug-resistance clinical isolates $S$. aureus 22/824 MRSA, S. haemoliticus MRCNS 134/3569, P. aeruginosa MBL 99/3066, P. aeruginosa MBL 125/3343, E. coli KPC 116/3196, K. pneumonia 6/509 ESBL, AmpC, KPC, A. baumannii 50/1496 MBL, A. baumannii $88 / 2995 \mathrm{MBL}$ at concentration from 7.8 up to $48.42 \mathrm{mg} / \mathrm{ml}$. This study is the first report about the antibacterial activity of $F$. betulina against $S$. haemoliticus and A. baumannii. The study showed that the antibacterial activity of $F$. betulina cultural liquid improved when it was concentrated and dried. The highest antibacterial activity was established in dried $F$. betulina cultural liquid and might be a perspective antibacterial substance in the pharmaceutical industries. Further studies are needed for isolation and determination of biologically active agents, responsible for the antimicrobial properties of $F$. betulina cultural liquid, which could be used in the treatment or prevention of many human diseases.

\section{References}

[1] Pleszczyńska, M., Lemieszek, M. K., Siwulski, M., Wiater, A., Rzeski, W., Szczodrak, J. (2017). Fomitopsis betulina (formerly Piptoporus betulinus): the Iceman's polypore fungus with modern biotechnological potential. World Journal of Microbiology and Biotechnology, 33 (5). doi: https://doi.org/10.1007/s11274-017-2247-0

[2] Utzig, J. Fertig, S. (1957). Influence of polyporenic acids on the growth of the bacterium of Brucella. Medycyna Weterynaryjna, 5, 268-269.

[3] Kandefer-Szerszeń, M., Kaczor, J,. Kawecki, Z. (1981). Fungal extracts as source of antiviral substances. II. Application of the chromatography methods for the isolation of antiviral substances from Piptoporus betulinus (Bull. Ex Fr.). Annales UMCS, XXXVI (1), 1-20.

[4] Kandefer-Szerszeń, M., Kawecki, Z. (1974). Ether extracts from the fruiting body of Piptoporus betulinus as interference inducers. Acta microbiologica Polonica. Ser. A., 6 (2), 197-200.

[5] Suay, I., Arenal, F., Asensio, F. J., Basilio, A., Cabello, M. A., Díez, M. T.et. al. (2000). Screening of basidiomycetes for antimicrobial activities. Antonie Van Leeuwenhoek, 78 (2), 129-140. doi: http://doi.org/10.1023/A:1026552024021

[6] Schlegel, B., Luhmann, U., Härtl, A., Gräfe, U. (2000). Piptamine, a New Antibiotic Produced by Piptoporus betulinus Lu 9-1. The Journal of Antibiotics, 53 (9), 973-974. doi: https://doi.org/10.7164/antibiotics.53.973

[7] Keller, C., Maillard, M., Keller, J., Hostettmann, K. (2002). Screening of European Fungi for Antibacterial, Antifungal, Larvicidal, Molluscicidal, Antioxidant and Free-Radical Scavenging Activities and Subsequent Isolation of Bioactive Compounds. Pharmaceutical Biology, 40 (7), 518-525. doi: https://doi.org/10.1076/phbi.40.7.518.14680 
[8] Tsvetkova, I., Naydenski, H., Petrova, A., Kostadinova, E., Gyosheva, M., Georgieva, P. et. al. (2006). Antibacterial Activity of Some Bulgarian Higher Basidiomycetes Mushrooms. International Journal of Medicinal Mushrooms, 8 (1), $63-66$. doi: https://doi.org/10.1615/intjmedmushr.v8.i1.80

[9] Karaman, M., Mimica-Dukic, N., Knezevic, P., Svircev, Z., Matavuly, M. (2009). Antibacterial Properties of Selected Lignicolous Mushrooms and Fungi from Northern Serbia. International Journal of Medicinal Mushrooms, 11 (3), $269-279$. doi: https://doi.org/10.1615/intjmedmushr.v11.i3.60

[10] United States Patent Application Publication US 20090130138 A1. Antiviral and antibacterial activity from medicinal mushrooms. Available at: https://patents.justia.com/patent/20090130138

[11] Vunduk, J., Klaus, A., Kozarski, M., Petrovic, P., Zizak, Z., Niksic, M., Van Griensven, L. J. L. D. (2015). Did the Iceman Know Better? Screening of the Medicinal Properties of the Birch Polypore Medicinal Mushroom, Piptoporus betulinus (Higher Basidiomycetes). International Journal of Medicinal Mushrooms, 17 (12), 1113-1125. doi: https://doi.org/10.1615/intjmedmushrooms.v17.i12.10

[12] Dresch, P., D’Aguanno, M. N., Rosam, K., Grienke, U., Rollinger, J. M., Peintner, U. (2015). Fungal strain matters: colony growth and bioactivity of the European medicinal polypores Fomes fomentarius, Fomitopsis pinicola and Piptoporus betulinus. AMB Express, 5 (1). doi: https://doi.org/10.1186/s13568-014-0093-0

[13] Alresly, Z., Lindequist, U., Lalk, M., Porzel, A., Arnold, N., Wessjohann, L. A. (2016). Bioactive triterpenes from the fungus Piptoporus betulinus. Records of Natural Products, 10 (1), 103-108.

[14] Bisko, N. A., Lomberg, M. L., Mytropolska, N. Yu., Mykchaylova O. B. (2016). The IBK Mushroom Culture Collection. Kyiv: Alterpres, 120.

[15] Krupodorova, T., Barshteyn, V., Kizitska, T., Kvasko, H., Andriiash, H., Tigunova, O. (2018). Effect of ultraviolet C irradiation on growth and antibacterial activity of Fomitopsis betulina (Bull.) B.K. Cui, M.L. Han and Y.C. Dai. GSC Biological and Pharmaceutical Sciences, 4 (3), 001-006. doi: https://doi.org/10.30574/gscbps.2018.4.3.0073

[16] MV 9.9.5-143-2007. Viznachennya chutlivosti mikroorganizmiv do antibakterialnih preparativ (2007). Ministry of Health of Ukraine. Kyiv, 74.

[17] Janeš, D., Kreft, S., Jurc, M., Seme, K., Štrukelj, B. (2007). Antibacterial Activity in Higher Fungi (Mushrooms) and Endophytic Fungi from Slovenia. Pharmaceutical Biology, 45 (9), 700-706. doi: https://doi.org/10.1080/13880200701575189

[18] Kalu, A., Kenneth, O. (2017). Antimicrobial Activity of Pleurotus squarrosulus on Clinical Pathogenic Bacteria and Fungi. Journal of Advances in Microbiology, 4 (3), 1-9. doi: https://doi.org/10.9734/jamb/2017/34644

[19] Kozarski, M., Klaus, A., Vunduk, J., Zizak, Z., Niksic, M., Jakovljevic, D. et. al. (2015). Nutraceutical properties of the methanolic extract of edible mushroom Cantharellus cibarius (Fries): primary mechanisms. Food \& Function, 6 (6), $1875-1886$. doi: https://doi.org/10.1039/c5fo00312a

[20] Matijašević, D., Pantić, M., Rašković, B., Pavlović, V., Duvnjak, D., Sknepnek, A., Nikšić, M. (2016). The Antibacterial Activity of Coriolus versicolor Methanol Extract and Its Effect on Ultrastructural Changes of Staphylococcus aureus and Salmonella Enteritidis. Frontiers in Microbiology, 7. doi: https://doi.org/10.3389/fmicb.2016.01226

[21] Nowacka, N., Nowak, R., Drozd, M., Olech, M., Los, R., Malm, A. (2015). Antibacterial, Antiradical Potential and Phenolic Compounds of Thirty-One Polish Mushrooms. PLOS ONE, 10 (10), e0140355. doi: https://doi.org/10.1371/journal.pone.0140355

[22] Xiao, J.-H., Xiao, D.-M., Sun, Z.-H., Xiong, Q., Liang, Z.-Q., Zhong, J.-J. (2009). Chemical compositions and antimicrobial property of three edible and medicinal Cordyceps species. Journal of Food, Agriculture \& Environment, 7 (3\&4), 91-100.

[23] Yamaç, M., Bilgili, F. (2006). Antimicrobial Activities of Fruit Bodies and/or Mycelial Cultures of Some Mushroom Isolates. Pharmaceutical Biology, 44 (9), 660-667. doi: https://doi.org/10.1080/13880200601006897 